\title{
Towards global management on flight and migration? A comparison of refugee politics in Europe and Asia
}

\author{
Reinhard Biedermann
}

\author{
Correspondence: \\ 134230@mail.tku.edu.tw \\ Department of Global Politics and \\ Economics, Tamkang University, \\ 180, Linwei Road, Chiao-hsi Shiang, \\ I-Lan County 26247, Taiwan, \\ Republic of China
}

\begin{abstract}
The United Nations High Commissioner for Refugees and leading Western and East Asian politicians demand coherent global management of migration and flight. This article wants to explore whether global management on refugees is feasible. It attempts to make these very different regions and regional mechanisms comparable aiming to contribute to a better intraregional understanding to raise common awareness. It compares the data on refugees and migration of the recent years to or within both regions, looking for interconnections. Then, it compares the structure, namely the legal framework in Europe and in Asia. This analysis will be followed by an agency analysis, under consideration of identity politics and discourse. The politicization of identity politics in both regions frames, and is framed by, decision makers towards global management options.

This paper concludes that global management of flight and migration has become more probable in recent years since the awareness has risen in both regions about this issue. The legal foundations in many Asian states are strengthened and orientate towards the UN refugee conventions, while the restrictive rich East Asian economies have begun to realise their responsibilities.
\end{abstract}

Keywords: Migration management, Global refugee policy, Refugees, EU, ASEAN, Identity politics, East Asia, World system theory

\section{Introduction}

The European refugee crisis has been challenging European institutions since August 2015. Yet, the crisis is not only a test for the European Union's (EU) Common European Asylum System (CEAS) and European rules on migration and refugee policy, but also for European values and identity. In 2015, one million refugees and migrants crossed the Mediterranean Sea mostly to Greece. At least 850,000 came from Turkey and crossed the Aegean Sea. Germany received 441,900 asylum claims, the most of any country that year (UNHCR Global Trends 2015) and the proclaimed "welcome culture" by the German government set incentives for yet more people to come to Europe and Germany.

Also Asia has its refugee crisis. Only a few weeks earlier the same year, thousands of boat people on refuge in the Bay of Bengal and the Andaman Sea coming from Myanmar caught worldwide media attention as well, but then were sidelined by the

(C) The Author(s). 2017 Open Access This article is distributed under the terms of the Creative Commons Attribution 4.0 International License (http://creativecommons.org/licenses/by/4.0/), which permits unrestricted use, distribution, and reproduction in any medium, provided you give appropriate credit to the original author(s) and the source, provide a link to the Creative Commons license, and indicate if changes were made. 
events in the Mediterranean. In early 2015, an estimated 25,000 Bangladeshi's and Rohingya Muslims from Myanmar boarded smugglers' boats, twice as many as in the same period of 2014 according to UNHCR. Most come to Thailand, where they are held captive until relatives pay a ransom. ${ }^{1}$ Thailand, Malaysia and Indonesia have policies in place to turn back any of the boats that reach their shores. In May 2015, thousands of Rohingya asylum seekers fled Myanmar on mostly small boats and trawlers, floating on the open sea at risk of drowning, disease, and dehydration. ${ }^{2}$

Asia and Pacific region was home to 9.8 million people of concern to UNHCR in 2015, including 3.8 million refugees, 2.9 million internally displaced people and many stateless people. The majority of refugees come from Afghanistan and Myanmar. The sea-routes in Europe and Pacific Asia are very dangerous for refugees. In 2015, at least 5740 migrants lost their lives or went missing during migration. More than 3770 occurred in the Mediterranean, and ca. 1000 in Pacific Asia (IOM 2015).

While the EU hosts hundreds of thousands of refugees, the wealthiest East Asian Nations South Korea and Japan accepted several hundreds of refugees only, while Australia has the strongest deterrence policy of all Western countries to close borders for Asian refugees. The rigidity of East Asian wealthy Nations against refugees made it into many media outlets sustained by heavy criticisms by civil society actors.

The United Nations High Commissioner of Refugees (UNHCR) does not discern between refugees, stateless people and economic migrants. Both mass movements to Europe and within Central and South-East Asia consist of complex, mixed migratory movements. Despite the intricacy, the UNHCR speaks about a global refugee crisis in need for coherent management and demanded global action to deal with the greatest flight of humanity since the Second World War. ${ }^{3}$ Also political leaders demanded global action. At a UN Conference in Washington on invitation US President Barrack Obama and a participation of 52 governments in late 2016, Co-host German Foreign Minister Frank- Walter Steinmeier stated that the world needed a "global management of migration". In accordance, the the G20 has turned its attention to the refugee crisis. In a statement the G20 said a "coordinated and comprehensive" response is needed to surmount the crisis. Demanding an international response and burden sharing of the crisis, the G20 Communique demands collective action on refuge settlement and admission, humanitarian aid and access for refugees to services, education and livelihood opportunities.

The goal of this paper is to explore, whether a global management is feasible, since the legal foundations, the political systems and organisation, and identity construction and identity politics are very different in these two regions. And even within these regions, there are stark differences as well. Nevertheless, this paper tries to find common minimum ground for a more coherent interregional management of migration, which arguably would be a major contribution to global management. The refugee regimes in both regions differ in legal and political terms. Differently to the EU, most ASEAN refugees come from within the regional grouping, namely ASEAN.

The relevant areas of international law are maritime, migration, criminal and transnational crime, human rights and refugee law. The 1951 Geneva Convention Relating to the Status of Refugees (amended in 1967 by the New York Protocol) has defined for over 60 years who, and who is not, a refugee and since then has been one of the cornerstones for the development of a common asylum system within the EU. Unlike EU 
Members, most ASEAN members have not signed the UN 1951 Refugee Convention or the 1954 Statelessness Convention. Europe and Asia are widely regarded as separate systems and at first sight appear as hardly comparable cases.

The next section introduces theory and methodology of the paper. It will be followed by the empirical data on refugees. The UNHCR, the EU, but also National institutions produce an immense amount of data. The main function is to illuminate the dimensions, and the problems in reading and interpreting them. This section then is followed by an analysis and comparison of legal foundations of refugee policy and Europe and in ASEAN and East Asia. Legal foundations only to a limited extent explain policy responses and actual refugee policy. Since politicization of identity or identity construction apparently played an important role, it is important also to shed light on changes during this critical juncture of this humanitarian crisis.

\section{Refugees in a world system and identity politicization}

Realist, liberal and Marxist theory in the international relations discipline tend to simplify the world system in differentiating in core and periphery. The core consists of the rich and most developed and powerful states, while the periphery are the developing and poor states. The periphery would export their raw materials cheaply and provide cheap labor costs, while the core would exploit the periphery and dominate with ther power. Immanuel Wallerstein's world system theory added the semi-periphery to core and periphery, which has certain features different to the core and to the periphery. ${ }^{4}$ The semi-periphery would act as a core for the periphery, while it was a buffer between the core and the periphery. Although this theoretical strand belongs to Marxist theory of dependency, I argue that it also adds to a better understanding of the refugee crisis in Europe and Asia. I argue that in a world system or refugees, there is also a semiperiphery, which acts as a core for the periphery. Moreover, the semi-periphery acts as a harbor for refugees, which is financed by the core to stop or at least manipulate migration from there to the core. Therefore, also in a world system of refugees with core, semi-periphery, and periphery, the semi-periphery acts as a buffer.

In the Western sphere of the Eurasian continent, the European Union's richest states would be the core, while Turkey and Northern African states are the semi-periphery. The semi-periphery acts itself as a core for the periphery and at the same time as a buffer between the periphery and the core. The semi-periphery is exploited by the core, but itself exploits also the periphery. An example would the human trafficker, that mostly come from the semi-periphery. In addition, states and governments of the semiperiphery "exploit" the refugees, since they often have no documents, titles, and remain sidelined to work in the informal sector. On the other side of the Eurasian continent, the core is clearly Japan, Korea, Singapore, and further away, Australia. Since these states are extremely closed for refugees and migrants, they also only contribute relatively little finance to UNHCR. The semi-periphery would consist of most ASEAN countries, and the periphery of the least developed countries and conflict zones like Pakistan, Afghanistan or Myanmar. For the goal of a common, coherent global management of migration, cooperation between the European and East Asian core states on how to deal with the respective semi-peripheries and regions is an indispensable prerequisite. In both regions identity discourses referring to refugee policies gained momentum, with an ongoing politicization. 
Regarding global rules on refugees, this paper will compare legal foundations in Europe and in Asia. Main emphasis naturally lies on the commitment to the Refugee Convention and other legal standards. The development of customary law will deserve special attention, since the Asian region has only a limited commitment to international treaties on refuge.

Social constructivists argue, identity is constructed and may change during crises and what they term as critical junctures. Identity is politicized in crisis situations, or what social constructivists call 'critical junctures'. ${ }^{5}$ Critical junctures test constructed identities. When the overall political and economic situation is stable, promulgated values or principles remain untested and stable. Civic identity constructions that focus on human rights, democracy, and concurrent civil and human achievements, like in the EU the Copenhagen criteria and the Lisbon Treaty of 2009. In crisis situations, underlying or 'real' identities may overlap or disturb such constructed, civil identities. Primordial identity focuses on historical and ethnic constructions of identity like race, culture, and so on. Primordial identity is the identity of choice in the semi-periphery, mixed with sacred identity. Sacred identity puts cultural and religious concepts in the center. Political elites, and sometimes intellectuals, are primarily responsible for developing narratives that link national histories and memories. ${ }^{6}$ Especially in and during critical junctures, national identity discourses culminate in state leaders expressions. The exploration of the refugee crisis and national narratives in this 'critical juncture' will make identity policies regarding the refugee crisis between 2014 and 2016 in the EU, ASEAN and East Asia comparable at an international level.

\section{The political geography of migration and refuge}

This section explores the data on recent migrants and refugee figures as presented from UNHCR, the EU Statistics Bureau Eurostat, the International Organisation for Migration, and the German Federal Office for Migration on refugees and migrants. The international organisations receive their information from national institutions of developed states or produce their own dates in developing countries, where they mostly operate, but where data is weak and hard to collect. It should be noted that it is difficult and rather impractical to discern between refugees and migrants. The following section compares the data on refugees and migrants in Europe and Asia in the respective core and semi-peripheries (or the G7 and G20 levels). First, we take a look on long-term trends presented by the IOM on migration, and then on the global refugee data from UNHCR.

According to International Organisation for Migration (IOM), one in seven people globally are migrants, including migrants within a country. In 2015,244 million were international migrants according to IOM. 51\% of those migrants live in ten countries only. The most popular destination is the USA, where almost 47 million foreign-born officially resided, followed by Germany with 12 million. Large migrant numbers in the EU belonging to the top ten globally also live in UK ( 8.5 million), France (7.8 million) and Spain (5.8 million). Related to population the highest rate in Europe resides in Sweden (17\%). Largest percentages of foreign-born migrant live in Western Asia. In Singapore, $45 \%$ of population is composed of international migrants. 28\% of Australians are also foreign-born.

The IOM collects also data on long-term trends of movements that are as follows. Most people migrate within the South and from South to the North (see Table 1). The 
Table 1 Distribution of international migrants, by origin and destination, 2015

\begin{tabular}{lll}
\hline Direction & Stock (million) & $\begin{array}{l}\text { \% of total } \\
\text { international } \\
\text { migrant stock }\end{array}$ \\
\hline South $\rightarrow$ South & 90,2 & $37 \%$ \\
South $\rightarrow$ North & 85,3 & $35 \%$ \\
North $\rightarrow$ North & 55,2 & $23 \%$ \\
North $\rightarrow$ South & 13,6 & $5 \%$ \\
\hline
\end{tabular}

largest movements are within the South, followed closely by South to North. Movements from North to South are considerably smaller.

Studying the data on refugees and "irregular migration" (a term used by IOM) needs careful examination, since different organisations have different methodologies and goals. Also political considerations play a role. For the UNHCR, working with high numbers may make it easier to generate funds. For National governments in Europe, working with lower numbers may make it easier to cushion negative sentiments of native populations against migrants. Only governments can grant refugee status, not the UNHCR. Human trafficking and smuggling is a global problem. The IOM estimates that there are at least 50 million irregular migrants worldwide (without a visa). The USA has the largest of ca. eleven million, Russia ca. three million (mostly Russians from the Ukraine). For Asia, IOM estimates suggested that there were four million undocumented migrants in Pakistan, and one million undocumented workers in Malaysia in 2006 (IOM 2015: 12).

In 2016, more than 65 million people have been forcibly displaced in their own country or have fled their home, the highest figure ever measured by UNHCR. ${ }^{7}$ Of these, 44 million forcibly displaced people found refuge within their own country. Roughly 21 million refugees registered with UNHCR left their home country. Of these, five million Palestinian refugees and their families are registered with UNRWA (United Nations Relief and Works Agency for Palestinians). In sum, UNHCR registered 16 million refugees internationally. More than eight million (53\%) worldwide came from three countries only: Somalia (1.1 million), Afghanistan (2.7 million), and Syria (5 million). ${ }^{8}$ Half of the refugees are below 18 years old. The three countries hosting the most refugees are Turkey (2.9 million), Jordan (658,000, both in April 2017), and Lebanon (1 million in December 2016). ${ }^{9}$ Prior to 2014 and since 2004 , some 900,000 refugees have arrived in industrialized countries through resettlement programs. These figures have dramatically increased to Europe since then. Between 2014 and 2015, ca. 1.8 million refugees and irregular immigrants have arrived in Europe via the Mediterranean Sea.

Does global management on flight and migration needs coordination between Europe and Asia? The UNHCR figures reveal, that only twelve percent of flight and migration takes place in the Americas, while the remaining 88\% takes place in Middle East (39\%), Africa (29\%), Asia Pacific (14\%), and Europe (6\%).

Table 2 shows that the asylum claims lodged in Europe have risen particularly strong in recent years till 2016. In parallel, figures for Australia and New Zealand have dropped dramatically in comparison. Japan and Korea witness the strongest increases in percentages, but from a low level. Japan and Korea are very repellent on refugees. Yet, there are also refugees from Middle East and Africa claiming asylum these East Asian countries, which supports appeal on a global management. It is possible, that 
Table 2 Asylum claims lodged in developed countries (UNHCR 2016, except figures from 2016: for EU: Eurostat; for the others: tradingeconomics.com)

\begin{tabular}{llllll}
\hline & 2012 & 2013 & 2014 & 2016 & $\begin{array}{l}\text { Changes } \\
(2014-2016)\end{array}$ \\
\hline EU-28 & 369,300 & 485,000 & 714,300 & 1,200000 & $68 \%$ \\
USA/CAN & 98,900 & 94,800 & 134,600 & 147,354 & $9.5 \%$ \\
AUS/NZ & 16,100 & 12,000 & 9200 & $?$ & \\
Japan/Korea & 3700 & 4800 & 7900 & ca. 19,500 & $147 \%$ \\
\hline
\end{tabular}

asylum claims to Japan and Korea also rose because of strong deterrence policies by Australia. In 2014, Korea only accepted refugee status to 94 people, up from 57 in 2013. Japan received 5000 applications but accepted just eleven people in 2014. In 2015, Japan received a record 7586 asylum applications, up 50\% compared to the year before. 99\% of applications were rejected. In 2016, the EU received the record number of 1.2 million first time asylum seekers registered. In contrast, Japan and Korea received only $1.6 \%$ of claims the EU-28 received (that is, 19,500). Japan and Korea together have almost 180 million inhabitants, while the EU-28 has 510,000,000. The EU population is roughly three times as high. If Japan and Korea would host a comparable number of refugees in 2016, the figures would have to increase by a factor of 16. However, at the General Assembly of the UN in New York, Abe insisted Japan must first tackle its domestic crises, namely the falling birth rate, an ageing population and needs continue to raise the number of women in the labor market, saying that "[t]here are many things that we should do before accepting immigrants. ${ }^{10}$ Asylum seekers from Nepal topped the list of those arriving in 2015, with 1768 submissions. The accepted applicants included six from Afghanistan, three Syrians, three Ethiopians and three from Sri Lanka. Abe pledged US $\$ 2.8$ billion in aid for refugees and migrants over 3 years from 2016, vowing to play a "leading role" in global efforts to address the "serious" humanitarian crises. ${ }^{11}$ However, this will hardly be enough to coordinate refugee policies efficiently on a global level.

The restrictive policies by Japan and Korea shall be cushioned by an ambition of coordination by monetary assistance. South Korea's President Park Geun Hye joined world leaders at the Group of 20 Summit in November 2015, held in Antalya, Turkey. "I believe the G20 should lead the efforts to share burdens and responsibilities being laid on the sources of refugees, their destinations and the countries in between. ... Korea, too, will help resolve the refugee problems by expanding humanitarian aid. ... This is line with South Korea's plan to increase its contributions to global concerns. ${ }^{12}$ South Korea granted asylum to 600 non-Korean refugees out of 18,800 applicants. In comparison, Austria with less than one fifth of Korea's population will accept roughly 38,000 asylum seekers in 2016.

Differently to Nation states, the UNHCR registers as many refugees as possible for humanitarian reasons. However, as we will see below, UNHCR is not only providing provisional shelter, but also helps refugees and migrants to better integrate in their host societies, like in Malaysia and Thailand. Different to the rather exclusive orientation of a Nation state to reduce and stop the influx of refugees, the UNHCR is inclusive for humanitarian and economic reasons. The oldest mission of UNHCR, the UNRWA, gives refuge to Palestinian people. It hosts about 5.2 million people, including the 
children who were born during the decades-long mission. UNRWA gives shelter, educates refugees, provides housing, medical treatment, and so on. This mission became a quasi-state. While UNHCR was founded on a budget of US \$100,000 in 1950 to protect Palestinians, it has a budget today of US $\$ 7.5$ billion today and employs roughly 30,000 people. Arguably, the higher the numbers of refugees, the more money UNHCR needs. However, the UNHCR is probably not a fully impartial organisation as well, since it is mostly financed by Western states, while the underlying refugee convention (see below) was very much a Western project after World War II.

UNHCR is predominantly financed by the USA, the EU and European governments (see Table 3). In 2016 it has had the biggest budget ever with US $\$ 7.1$ bn. In addition, and to finance the unmet needs with public contributions, roughly $14 \%$ of financial contributions come from private funds. The EU funds consists of contributions from the European Commission and the individual member states budgets. The UNHCR registers refugees in those countries that are Parties of the refugee convention from 1951. Since it is fully dependent on voluntary contributions from the governments from the industrialized countries, they stem the largest influence on UNHCR policies. Not only the richest states finance UNHCR, but also those that are the most attractive for refugees. Germany, for instance, contributes much more than Japan or China. However, the open and attractive Scandinavian countries, related to their populations, contribute more than Germany, which receives special appreciation by UNHCR. ${ }^{13}$ Semi-peripheral states like Turkey are hosting many refugees, since UNHCR and EU assist Turkey in dealing with the crisis, while they themselves only provide very limited funding.

Time inconsistencies make comparisons between UNHCR and European figures problematic. The top five countries harbouring refugees on June 302016 according to UNHCR were Turkey with 2,773,800 refugees, Lebanon (1,035,700), Islamic Republic Iran $(978,100)$, and Pakistan $(1,576,800)$. Pakistan, which is not Party of the Refugee

Table 32016 top Government Donors to UNHCR (UNHCR, Donors, http://www.unhcr.org/ donors.html)

\begin{tabular}{lll}
\hline Rank & Donor & US\$ \\
\hline 1 & USA & $1,493,799,619$ \\
2 & European Union & $341,606,227$ \\
3 & Germany & $283,888,027$ \\
4 & Japan & $164,726,114$ \\
5 & Canada & $117,250,790$ \\
6 & United Kingdom & $113,854,401$ \\
7 & Sweden & $109,397,030$ \\
8 & Norway & $94,126,671$ \\
9 & Netherlands & $57,991,547$ \\
10 & Denmark & $55,530,063$ \\
12 & Australia & $39,897,526$ \\
19 & Republic of Korea & $20,051,630$ \\
49 & Turkey & $1,000,000$ \\
75 & Indonesia & 60,000 \\
75 & Singapore & 60,000 \\
93 & Thailand & 20,000 \\
\hline
\end{tabular}


Convention of 1951, sent back 600,000 refugees to Afghanistan during 2016. While UNHCR figures also include the children of refugees, like in UMRA, there is no statistical investigation of family reunion in Germany, and there is much speculation about how any family members will follow in the years to come, not least from camps in Turkey. Time inconsistencies between UNHCR and National data fabrication also exist because of the slow bureaucratic process testing asylum applications in Europe, but also in Korea or Japan. UNHCR registers fast due to its inclusive approach. European and other industrialized countries instead check whether refugee status is eligible. The UNHCR refugees of $16,000,000$ are only provisionally registered. They may leave the refugee camp whenever it fits to them to go where they assume to find a better life.

Yet more complicated are the figures for Asia and ASEAN in particular. Most countries are not Parties of the refugee convention. Still, UNHCR is active in many countries. The Asia and Pacific region is home to 7.7 million people of concern to UNHCR. They include 3.5 million refugees, 1.9 million IDP, and 1.4 million stateless people. The majority of refugees originate from Afghanistan and Myanmar. The Afghan refugee population constitutes the largest protracted situation in the world. More than $90 \%$ of all Afghan refugees live in the neighboring Islamic Republics of Iran and Pakistan, which have hosted them for over three decades. In 2015, almost 180,000 refugees from Afghanistan applied asylum in European countries. However, no refugees from Myanmar appear in the statistics. Taylor (2016) writes that despite Asian Pacific countries are not Parties of the Refugee Convention, humanitarian considerations result in tolerating the unauthorized presence of asylum seekers and refugees within their borders most of the time (Taylor 2016:3). The Myanmar situation also remains a key operation. An estimated 500,000 refugees from different ethnic groups have been fleeing for several decades in search of protection from ethnic conflict and violence to various Asian countries.

According to UNHCR figures, there were over 520,000 refugees and asylum seekers in 2014 in the Asian region, of whose around 150,000 were formally registered. In addition, UNHCR estimates that almost 1.4 million stateless persons and 20,000 "irregular maritime migrants" were in the region. Asylum seekers in South-East Asia come from Bangladesh, China, Pakistan, Sri Lanka, North Korea, and from some nonAsian countries Syria, Somalia and even the Balkans. Not only in Asia, but also in the EU refugees may be termed illegal migrants by European Parties of the Refugee Convention. ${ }^{14}$

The only potential core countries in Asia, comparable to those in the EU, are therefore Japan and Korea. However, they are also the most restrictive ones in comparison. ${ }^{15}$ In Western media, the rich East Asian countries Japan and South Korea have received augmenting criticism because of their strict refugee policy. ${ }^{16}$ The German public radio Deutsche Welle broadcasted globally that Japan has the lowest refugees recognition rate of all developed countries. Deutsche Welle titled "No country for refugees? Japan and South Korea's tough asylum policies. Syrians Seeking Asylum in South Korea Find Only a Cold Shoulder."17 Even Malaysia accepted much more refugees from Syria than Korea and Japan together. Korea's and Japan's geography and distance do not seem to be the main reason to not flee to East Asia from distant places. The largest number of refugees comes from Turkey (658), followed by Nepal (544), and Myanmar (380). The largest number of asylum seekers came from Pakistan, Sri Lanka and Nepal. Those 
streams, although limited compared to Europe, support the idea of a demand of global management.

Not all refugees appear on UNHCR statistics. Countries that host refugees but are not member of UNHCR may not publicize figures or UNHCR does not count them. For instance, the figures on Table 3 by UNHCR are fabricated completely different. In Turkey, the UNHCR counts every individual (see Table 4). Many refugees find shelter in provisional refugee camps (the Fig. 1). Roundabout one million asylum seekers in Turkey in 2015 have been granted temporary protection by UNHCR. Only relatively few people direct their asylum applications to Turkish authorities. This means, that only comparatively few people want to stay in Turkey. This is very different to Germany, where all asylum applications go to German authorities. In Germany or Sweden, each recognized refugee has undergone asylum application procedures. Hundreds of thousands of refugees that came to Germany in 2015 are not on the list yet. Developed countries that provide assistance to refugees are also not registered by UNHCR, but by those countries and institutions. UNHCR receives figures from the EU, while the EU relies on National evaluations. Yet, they may use different methodologies to count migrants and refugees in their countries or define them in different ways. Many unregistered Syrian refugees for instance are in the rich Middle Eastern countries. These countries are not signatories of the convention. Also countries like Afghanistan or Pakistan have millions of unregistered refugees, mostly internally displaced people (see Table 5).

A very instructive tool for getting data on refugees to European countries and from individual countries is Eurostat. ${ }^{18}$ It tells that in 2016, the EU-28 received 335,160

Table 4 People recognized as refugees in 2015, by country of asylum (UNHCR 2016)

\begin{tabular}{lll}
\hline Country & Refugee number & \\
\hline Turkey & 961,955 & 1 \\
Russian Federation & 149,662 & 2 \\
Germany & 143,548 & 3 \\
Tanzania & 123,582 & 4 \\
Uganda & 85,929 & 5 \\
Sudan & 83,753 & 6 \\
Ethiopia & 74,693 & 7 \\
Rwanda & 72,895 & 8 \\
Cameroon & 71,477 & 9 \\
Dem. Rep. of Congo & 62,699 & 10 \\
Lebanon & 56,718 & 11 \\
Jordan & 52,747 & 12 \\
Niger & 45,225 & 13 \\
Sweden & 33,207 & 14 \\
Italy & 29,614 & 15 \\
France & 26828 & 16 \\
United States & 23,361 & 17 \\
Kenya & 21,624 & 18 \\
United Kingdom & 17,168 & 19 \\
Austria & 16,891 & 20 \\
\hline
\end{tabular}




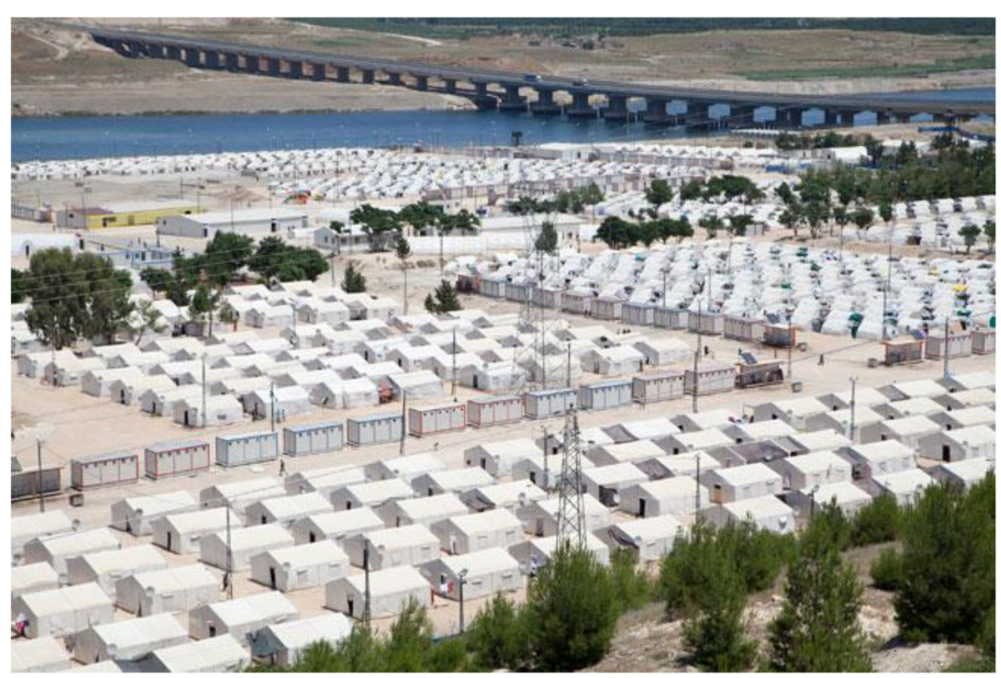

Fig. 1 Photo by UNHCR/E. Dorfman: "A 'guest camp'for Syrian refugees in Turkey" (title by UN), taken from http://www.un.org/apps/news/story.asp?NewsID=45112

asylum application from Syria, 126,915 from Iraq, and 182,780 from Afghanistan. Alone from Syria and between April 2011 and October 2016, European authorities submitted to UNHCR the figure of 884,461 Syrian Asylum applications in Europe. Many of these were Syrians that already came to Europe in 2015. Those figures also do not differentiate between first or repeated applications. They also reveal little information about the

Table 5 The Global Refugee Crisis: "Refugees and asylum seekers 2015, by country of origin", data modelled after figures from http://www.refugeecouncil.org.au/getfacts/statistics/unchr2015/

\begin{tabular}{lllll}
\hline Country & $\begin{array}{l}\text { Refugees and refugee } \\
\text { like situation }\end{array}$ & Rank & Asylum Seekers & Rank \\
\hline Syria & $4,872,585$ & 1 & 245,844 & 2 \\
Afghanistan & $2,666,254$ & 2 & 258,892 & 1 \\
Somalia & $1,123,052$ & 3 & 56,772 & 12 \\
South Sudan & 778,697 & 4 & 4237 & 58 \\
Sudan & 628,770 & 5 & 45,102 & 16 \\
Dem. Rep. of Congo & 541,499 & 6 & 76,418 & 5 \\
Central African Rep. & 471,104 & 7 & 10,668 & 37 \\
Myanmar & 451,807 & 8 & 60,659 & 8 \\
Eritrea & 411,342 & 9 & 63,446 & 7 \\
Colombia & 340,240 & 10 & 6905 & 49 \\
Ukraine & 321,300 & 11 & 22,574 & 24 \\
Vietnam & 313,156 & 12 & 4372 & 56 \\
Pakistan & 297,835 & 13 & 64,085 & 6 \\
Burundi & 14 & 26,893 & 22 \\
Rwanda & 292,764 & 15 & 10,957 & 36 \\
Iraq & 286,366 & 16 & 237,166 & 3 \\
China & 264,107 & 17 & 57,705 & 9 \\
Nigeria & 212,911 & 51,863 & 14 \\
Mali & 167,988 & 9906 & 14,869 \\
Sri Lanka & 154,211 & & & 28 \\
\hline & 121,435 & 19 & & 30 \\
\hline
\end{tabular}


real figures of refugees in Europe, since it is unknown how many refugees did not register. Hundreds of thousands asylum applications have been turned down in recent years.

Institutions involved in collecting data on refugee and migration data differ in statistical investigation. Those differences can be explained by time inconsistencies, different data investigation, and political rationality and motivation. It is clearly articulated goal of the German government to reduce the refugee influx. The rejection rates are very high. In each year since 2006, between 25 and 58\% of asylum applications have been rejected. Many refugees come from former Yugoslavia whose applications are regularly turned down. The responsible authorities in the federal states handle the problem differently. Rejected applicants often stay in Germany, and the government continues to support them financially with an amount comparable to long-term unemployed German Nationals. In June 2016, more than half a million people whose asylum applications where rejected, continue to live in Germany. Since many of them stayed in Germany longer than 6 years already, they received permanent residence status. ${ }^{19}$

This section focused on the pitfalls of refugee data through the lenses of political geography. In a world system of refugees, the industrialized core states as principals use the UNHCR as their agent to rationalize and manipulate refugee preferences. Those states that are the most open to refugees also contribute the largest funds, like the Northern European States, the USA, and Germany. Most refugees are internally displaced people. There are interdependencies between Europe and Asia regarding refugee choices and policies, however, they do not seem to be very strong. It is rather improbable, for instance, that as many Syrians would flee to Japan when Japan had the same policies of openness in place like Germany. This is because most refugees tend to stay in their region or find refuge geographically closed to them. Yet, there is growing awareness internationally about how much contributions individual countries make to work on the refugee crisis. East Asian countries only make marginal contributions, while they strongly benefit efforts of other countries, not least the Southeast Asian countries that have to deal with a large influx of refugees. The next sections deal with the legal foundations of a global refugee policy in the two regions. It focuses largely on international law and on regional regimes.

\section{Refugee and asylum policy: convergence or divergence?}

Institutions may have a deciding role whether global management and interregional coordination between Europa and Asia on refugees is feasible. Institutions as understood here include organisations and international and national law. If the institutions converge or are similar, interregional management is easier to achieve than when institutions strongly converge. Any cooperative mechanisms based on dominance or hierarchy are probably unrealistic. Coordination based on reciprocity and common identity appears as the more feasible way to go.

\section{Global customary law}

The European and the South and Southeast Asian Region are very different regarding their commitment to the refugee convention. While Europe is the only continent, where all countries are signatories of the Convention and the Protocol of 1967, the latter is the region with the most non-signatories. 43 states are not signatories or have 
not ratified the treaty, although they host large refugee contingents, notably in ASEAN. Only the Philippines (since 1981) and Cambodia (since 1992) of ASEAN are signatories. Malaysia, Thailand, Indonesia, Myanmar, India, Pakistan, Vietnam and even Singapore are all non-Parties. South Korea and Japan are both members. Hence, the initial situations in an interregional comparison look very different. Being a non-Party does not exempt those states from customary law. The central principle of nonrefoulement belongs to customary law. It states that refugees cannot be sent back to countries where they fled from when the conditions they fled have not changed and are covered by the Convention. Yet, many other important matters are not customary law or are at least disputed. Contracting partners give refugees the right to receive travel documents, free access to courts, administrative assistance, identity papers, the right to transfer their assets, rights related to marriage, and so forth. These examples show the centrality of the convention for the refugees.

The UN Convention on the Law of the Sea of 1982 is substantial for refugee policy, since search and rescue at sea is a humanitarian act and a seafaring tradition. It requires coastal state to "promote the establishment, operation and maintenance of an adequate and effective search and rescue service regarding safety on and over the sea and, where circumstances so require, by way of mutual regional arrangements cooperate with neighbouring States for this purpose." All five most affected countries of the Bay of Bengal situation (Bangladesh, Myanmar, Thailand, Indonesia, Malaysia) are parties of it. UNHCR argued that the region is clearly confronted by circumstances that require close cooperation on these obligations. ${ }^{20}$

UNHCR demands capacity building in countries of transit and first asylum. Although many countries in the region have not ratified the 1951 Refugee Convention, "they are nevertheless bound as members of the community of nations to observe customary international law principles prohibiting the return of individuals to places where their lives or freedom would be in danger...". ${ }^{21}$ Countries of the region are also Parties to the UN Convention Against Transnational Organized Crime and the attached Protocol on Trafficking in Persons, and attached Protocol on Smuggling of Migrants by Land, Sea and Air. So for the most pressing problems in the Mediterranean in Europe and the Bengal Sea in South Asia there are the same principles and rules in place.

\section{Regional policies in EU and ASEAN}

The European Union's normative and legal foundations are to be found in a Charter of Fundamental Rights which is legally binding for all EU members since the Lisbon Treaty is in force since 2009. The Article 2 of the Treaty on European Union (TEU) provides that 'the Union is based on the values of respect for human dignity, freedom, democracy, equality, the rule of law and respect for human rights, including the rights of persons belonging to minorities. There is no comparable strong commitment within ASEAN or in Asia to be found at regional level. The Lisbon Treaty and the Dublin Rules would EU members bind legally to cooperate with each other and implement the rules.

The European Commission Directorate General Migration and Home Affairs is in charge for developing EU policies on asylum. Since 1999, the EU has worked towards creating a common European asylum regime in accordance with the Geneva Convention and other international instruments. Between 2011 and 2013, the EU agreed on four main 
legal instruments on asylum. The latest one, the Dublin Regulation (EU) 604/2013 ${ }^{22}$ established the criteria and mechanisms for determining the Member State responsible for examining an application for international protection in one of the Member States by a third-country national or stateless person. This system collapsed and is now under recreation. The transfer of competences in asylum policy from Member States to the European Union, despite guided by the goal to improve and harmonize diverse standards, has resulted in an uneven sharing of responsibilities for asylum seekers between Member States and a deterioration in guarantees of fundamental refugee rights. Already before 2014 the entire asylum system in the European Union was interpreted as dysfunctional and of questionable conformity with the 1951 Geneva Convention. ${ }^{23}$ Whether the EU was able to better harmonise flight and migration standards looked already bleach before the crisis fully materialized. ${ }^{24}$ At the core of EU's refugee and asylum policy stands the Dublin Regulation. ${ }^{25}$ Refugees have to be registered in the country where they first set their feet. Naturally, this will more often happen in the Southern periphery of the EU than in landlocked Austria surrounded by EU members. This system therefore put middle European countries in a more comfortable position. However, around autumn 2015, this system collapsed when tens of thousands of refugees streamed over the Balkan through Hungary. Before, Hungary was one of the countries that received the most asylum claims in relation to population size.

The solidarity between the EU members to share responsibility is a major problem within the EU. The EU failed to distribute 160,000 refugees as decided by the European Council in September 2015 on its member states among a Union of 510 million inhabitants. Half a year later, only 660 refugees (that is: $0.17 \%$ ) have been relocated among the states. The refugees and migrants comprised mostly younger men and unaccompanied minors from conflict regions. Not only within Europe but also globally, Merkel chose for a German "Sonderweg" (special path), as notably conservative observers opined with a critical subtext. ${ }^{26}$

Liberals and the political left supported her policies unconditional, and she and Germany found worldwide ostensible admiration. She became the Time Magazine's "Person of the year 2015", and her quotes like "If Europe fails on the question of refugees, then it won't be the Europe we wished for", and particularly in Germany "We will cope"(Wir schaffen das) became famous, if not infamous, expressions. However, some perceive Merkel's policy as dictating "moral imperialism" (said by Victor Orban, Premier of Hungary and most outspoken critic of Merkel) on other European countries. ${ }^{27}$ During 2016, Merkel had to change her Willkommenskultur (welcome culture), not least because some refugees turned out to be terrorists and doubts arose about "wir schaffen das".

Meanwhile the EU, captured by German insistence, broke a deal with the Turkish government on 18 March 2016 to manage the refugee crisis and fight human trafficking on the Mediterranean. Turkey was promised 3 billion $€$ in support for the Syrian refugees in Turkey and in exchange for an agreement that keep Syrian refugees in Turkey. In addition, every captured refugee that would illegally try to come to Europe over the Mediterranean on human trafficker boats would be exchanged legally with a Syrian refugee hosted in Turkish refugee camps ("one in, one out"). The EU, notably Germany, would accept refugees from Turkey's up to three million hosted refugees. The EU hopes to cut off unregulated refugee inflow, and undermine human traffickers' economic base. 
After being active for 1 year, only 3500 refugees from Turkey have been exchanged. Human rights organisations criticize that agreement since it would provide only marginal legal option to go to Europe, while more and more refugees would suffer from depression. Turkey, with its questionable human rights standards and poor democracy and as a destination and source for refugees like from Kurdistan, can be seen as prime example for a semi-peripheral transit state in the European-Middle East theatre. It is not only hosting refugees, but since 2016 also a state that generates refugees through repressive policies against the own population. The EU has plans to negotiate similar plans with Egypt and Libya, two countries with yet more questionable human rights performance and security record for vulnerable refugees.

The ASEAN founding charter (Bangkok Declaration) was adopted in 1967 and future members prescribed non-interference in member states' domestic policies, which stemmed from opposition to colonialism and Cold War military expeditions, as well as conflicting cultural and religious heritage. Not established before 2009, the ASEAN Intergovernmental Commission on Human Rights (AIHCR) is still regarded as "toothless" by many, and the ASEAN's human rights declaration of 2012 was dismissed as a "declaration of government powers disguised as a declaration of human rights. ${ }^{28}$ Therefore, there is no regional framework for refugee policy. Accordingly, for the ASEAN Intergovernmental Commission on Human Rights, refugees have not been an issue since years. For instance, the last contact this Commission had with the UNHCR was in 2011, and dealt with the topic of Statelessness, women, and children rights. ${ }^{29}$ Yet, ASEAN was portrayed as central organisation for an Asian contribution to deal with the global refugee crisis. ${ }^{30}$ And media reports spoke about "ASEAN's refugee crisis"31.

De facto, ASEAN has no visible input in the crisis. Security relations in ASEAN are coined by mutual mistrust, which is also reflected by the refugee problematic. As a consequence, countries try to internationalize or globalize the issue by calling on the UNHCR, as had been seen in the 2005-2006 refugee stand-off between Malaysia and Thailand and the case of 131 Thai Muslims that fled to Malaysia. ${ }^{32}$ Refugees are treated as illegal intruders in ASEAN states, where they are at risk of all forms of vulnerability in society. ${ }^{33}$ Within ASEAN, refugees are often categorized as "irregular migrants," which includes both economic and political migrants (IOM 2015). The equivalence of political and economic flight reasons enables ASEAN countries to ignore humanitarian needs of refugees who flee conflict and persecution as opposed to those who have migrated for economic reasons.

Malaysia promised to open its doors to 3000 Syrian migrants over the next 3 years from 2015 on to help alleviate the refugee crisis. At the 70th session of the United Nations General Assembly Minister Datuk Seri Najib Razaksaid that "we must respect our common humanity" and the fleeing of millions of Syrians from their own country should be a world concern.

Thailand, Malaysia, and Indonesia are countries of refuge, but themselves also countries with weak implementation of basic human rights and refugee protection. They are in many ways equivalent to Turkey in the European theatre as semi-peripheral states.

\section{Implementation of refugee protection at national level}

In ASEAN, few countries have a domestic legal framework for determining asylum seekers' protection claims or protecting refugees. ${ }^{34}$ None are willing to provide refugees with a durable solution in form of location integration. They live in permanent danger 
of abuse and resettlement. Yet, National governments try to improve the situation. One incentive is that, similar to Europe, many countries in the region have low fertility rates and populations grow old. This holds not only true for South Korea and Japan, but also for Thailand or Malaysia. The Thai government has recognized that refugees and migrants can contribute to sustainable economic development in future generations. The Thai government has a policy of 'education for all', which means children in Thailand have a right to attend school regardless their or their parent's migration status. This is a very central policy Turkey for instance does not provide. Education for children sets incentives for refugees and migrants to not move on to other countries and to have a good integration prognosis.

Excluding asylum seekers on basis of identity is not a solely Western phenomenon. ${ }^{35}$ Australia and Malaysia use the term of "irregular migrants" since they fear threats posed for their national identity and security. The 'Malaysia Deal' in 2011 and accompanying political debates described asylum seekers and refugees as 'illegal', 'queue jumpers', and 'boat people'. ${ }^{36}$ Also Thailand would have a "criminalizing immigration framework" concurrent to the bleak refugee rights protection landscape of South-East Asia. $^{37}$

On the other hand, the clearly peripheral state of Cambodia signed a 'trade deal' to accept refugees from tiny Pacific Island Nauru, in exchange for a US \$35 million aid deal with Australia. This deal only superficially resembles the deal, Germany/the EU has made with Turkey, since the repatriated refugees from Uighur to China may expect torture or capital punishment. This gives an example about how problematic direct deals between the core and the periphery from human rights perspective are. Since National governments are passive on refugees, the UNHCR plays an important role to improve the status of refugees and migrants in Asian countries.

In September 2014, almost 150,000 refugees and asylum seekers were registered with UNHCR in Malaysia. For Muslim people in Asia, Malaysia with its predominantly Muslim population is seen as a country of choice. However, the refugees are consistently referred as a burden. ${ }^{38}$ Malaysia has no legal or administrative framework in place in order to address the refugee situation. According to the UNHCR, this creates a situation of great unpredictability and difficulty for refugees as a lack of their official status. There is no distinction by law from undocumented migrants. Therefore, refugees are at risk of arrest, detention, and deportation for immigration offenses. They are allowed to work only in the informal sector. They do jobs the local population does not like to do and are very vulnerable to exploitation with lowest or no wages at all. Their children do not have access to formal education. Although they have access to healthcare, they very often cannot afford it. This lack of institutions has been figured out by the UNHCR who presents several recommendations to improve the situation. This recommendation not least show clearly what is lacking for refugees currently. UNHCR recommends to

- Establish effective, predictable disembarkation to a place of safety

- Establish or enhance reception facilities (with regional and international support)

- Identification and treatment of those with international protection needs

- Facilitate solution for persons in need of international protection

- Support for returns of those not in need of international protection, like to facilitate the return of such individuals in conditions of safety and dignity. 
- Reinforce the gathering, sharing, analysis and use of information related to movements by the sea

- Expand legal alternatives to dangerous movements

For Malaysia the UNHCR plans for 2017 are as follows: 22,000 eligible persons shall be registered and provided with identity cards issued by UNHCR, the resettlement of 10,000 refugees estimated to depart for resettlement in third countries; the registration of 6949 registered children to be enrolled in primary education; 3300 people of concern will be provided with information on comprehensive solutions, including resettlement, and 2000 people will be released from detention through various intervention modalities. ${ }^{39}$ These examples show the important role of UNHCR for harmonising and helping global rules to emerge in legal terms ${ }^{40}$. While many ASEAN countries are not Parties of the Refugee Convention, they still allow UNHCR to actively set standards, which arguably become customary international public law.

Thailand is currently home to some 103,300 Myanmar refugees, living in nine camps along the Thailand-Myanmar border and mainly of Karen, Karenni, Burmese and Mon ethnicity. Refugees first arrived there in the early 1980s after fleeing ethnic conflict in south-eastern Myanmar, making this one of Asia's most protracted refugee situations. UNHCR in Thailand decreased the numbers of people of concern in 2015 compared to 2014 by $13 \%$ to 560,000. Its plans for 2017 are to repatriate 50,000 refugees from Myanmar through facilitated through voluntary repatriation; 20,000 stateless people will receive counselling and assistance in preparing citizenship applications, 4300 refugee children from Myanmar living in camps at the Myanmar-Thailand border will be registered and provided with birth certificates; people will be assisted through cash-interventions; 1000 children will be enrolled to Thai language classes. ${ }^{41}$ UNHCR figures said that people of concern were decreased from 644,000 to 560,000 from 2014 to 2015 .

Deterrence policies are adopted by many countries to prevent refugees from accessing protection and interact with international law on refugees in a process of co-evolution. ${ }^{42}$ International refugee law was not powerless since a growing number of states adopted the Refugee Convention of 1951. However, certain states also try to contest or circumvent their international legal commitment. For Taylor (2016:4), Australia is particularly an example for the Asia-Pacific region to apply strategy of deterrence. According to its critics, it would apply a 'regional deterrence framework' (Coalition 2013). ${ }^{43}$

The rich states of East Asia, namely Japan and South Korea, have the strictest policies on refugees. Japan and Korea signed the Refugee Convention only in 1981 and South Korea in 1992, respectively. ${ }^{44}$ Japan consistently has recognized very few refugees, despite being a wealthy democracy and strong supporter of the international system. ${ }^{45}$

For instance, Japan accepted only eleven candidates out of 5000 asylum applications in 2014. To diminish criticism on Japan's immigration policy, Japan became one of the largest UNHCR donors. Japan's Ministry of Justice is considering changes that could make it harder for applicants to seek asylum in Japan. From 2017 till 2020, Japan's government plans to provide US $\$ 2$ bn for refugees. However, there are no plans to make it easier for refugees to come to Japan. Japan's identity construction (see below) is a major reason for the restrictions. 
In 2011, the National Assembly of Korea passed the Law on the Status and Treatment on Refugees, which went to effect in 2013. A recent study claimed that Korea's refugee law still possesses problematic provisions related to detention, refugee determination, economic and social rights of asylum seekers, and the treatment of recognized refugees. ${ }^{46}$ The definition of what refugees are is key to many deterrence policies. People that flee conflict will not be recognized. ${ }^{47}$ Katrin Park, a former U.N. staffer, argued that both Korea and Japan simply bankroll others, which would not demonstrate international solidarity.

\section{Migration and identity discourse}

For the first time, the IOM made an attempt on a global conducted ballot to explore attitudes of people on migration. ${ }^{48}$ More than 183,000 adults across more than 140 countries between 2012 and 2014 were asked two question by Gallup. They were asked two questions on immigration: 1) In your view, should immigration in this country be kept at its present level, increased or decreased? 2) Do you think immigrants mostly take jobs that citizens in this country do not want (e.g. low-paying or not prestigious jobs), or mostly take jobs that citizens in this country want? A major finding of this report is that in every major region in the world, people are more likely to want the same levels of immigration or increased. The only exception was Europe: "European residents appear to be, on average, the most negative globally towards immigration, with the majority believing immigration levels should be decreased" (IOM 2015: 1). The report also confirms a sharp divergence between North and South Europe. There are socioeconomic differences that explain people's attitudes. Adults from countries with high unemployment rates are most negative towards immigration, whereas residents of high-income countries are more positive on immigration, and say that immigrants mostly take jobs the citizens do not want. This report identified regions and countries attitudes on migration, examined the relationship between economics and attitudes, identified where and among which demographic groups immigration is more or less accepted, and compare how public opinion aligns with government immigration policy.

Table 6 selected the G20 countries that are of interest in this exploration. Those European and Asian G20 countries that belong to the core and the semi-periphery are exposed. For the EU in sum it shows that only a minority is for the same or increased immigration levels. For Japan and Korea the figures indicate a majority for same and increasing levels of immigration. The following section takes a more detailed look into the elite discourse in EU during September 2015 till March 2016 (the EU-Turkey deal). I argue that this period marked a 'critical juncture' during which the identity discourse change. Also populations became more negative towards immigration and refugees, for various reasons. The civic identity construction of Europe was the mainstream in European societies, which also was represented by the IOM ballots.

The IOM study was made before the refugee crisis fully materialized in 2015. Germany belonged to the group of wealthy states with low unemployment, that was very friendly towards immigration. This overall orientation of the population was also represented in Merkel's reaction. In August 2015, or Merkel called for EU member states to "share responsibility for asylum-seeking refugees". She also emphasized Germany needs man power, which is a significant difference to other EU states, which partly may explain the German Willkommenskultur: "[...] for Germany, Europe is not only 
Table 6 Attitudes towards migration in selected G20 countries (\%)

\begin{tabular}{lllll}
\hline & Present level & Increased & Decreased & No answer \\
\hline Australia & 40 & 30 & 35 & 6 \\
China & 19 & 25 & 15 & 40 \\
France & 40 & 6 & 44 & 10 \\
Germany & 49 & 14 & 34 & 2 \\
Indonesia & 18 & 4 & 45 & 33 \\
Italy & 28 & 3 & 67 & 2 \\
Japan & 36 & 29 & 16 & 19 \\
Rep.o. Korea & 30 & 27 & 27 & 15 \\
Turkey & 26 & 7 & 53 & 14 \\
UK & 24 & 5 & 69 & 2 \\
EU & 36 & 8 & 48 & 8 \\
\hline
\end{tabular}

In your view, should immigration in this country be kept at its present level, increased or decreased?

Source: IOM 2015: How The World Views Migration, Global Migration Data Analysis Centre, Berlin

indispensable, it is part and parcel of our identity. We've always said German unity, European unity and integration, that's two parts of one and the same coin. But we want, obviously, to boost our competitiveness." However, the German Willkommenskultur has been bit by bit abandoned since late 2015, early 2016. Incidents like sexual harassment by Northern African groups on New Year in Cologne 2015/6, several terrorist attacks or planned attacks that were impeded by police, and a lethal terrorist attack on a Christmas Market in Berlin end of 2016 all contributed to the changing public mood. A European dispute about who should take how many refugees emerged already since September 2015. Frederica Mogerini, the former Italian Foreign Minister and EU's highest foreign policy representative opined, "ii]f we are not able to share 40,000 refugees, then we are not a Great Europe capable of involvement in world affairs. Our credibility will collapse. ${ }^{\text {"A } 9}$ A heated debate in the EU emerged also about identity and values. In the Netherlands, a rich European core country, right-wing voices gained considerable weight. There, the opposition politician Geert Wilders accuses Muslims of "barbarism". France always belonged to the top three countries to accept refugees in recent years, although the IOM ballot showed ambivalent figures of support. French President Francois Hollande, in defence of a liberal policy, said public opinion was fickle but asylum was a constitutional right and a moral duty. ${ }^{50}$ The largest refugee camp in Northern Europe is to be found in Calais in Northern France, where thousands of people hold out in misery slum conditions for their impossible migration to England. The British government became tough on refugees. David Cameron's British premier spoke of "swarms" of migrants seeking to "break into Britain".

Central and Eastern European members of the EU are the most restrictive countries. Four countries-Hungary, Slovakia, the Czech Republic and Romania-voted against the plan to share the responsibilities for refugees in September 2015, while Finland abstained. Viktor Orban, prime minister of Hungary, perceived the refugees as a threat to European civilization: "We don't know if Europe will remain an advanced and united continent or if it will be destroyed, as happened with the barbarian invasions. ${ }^{51} \mathrm{Mr}$ Orban's announcement came after a prominent member of his ruling centre-right 
Fidesz party claimed that the "the very existence of Christian Europe" was under threat. Antal Rogan, the parliamentary group leader, said: "Would we like our grandchildren to grow up in a United European Caliphate? My answer to that is no". He feared being "overrun"by Muslims, that would destroy the Christian roots: "That is an important question, because Europe and European culture have Christian roots. Or is it not already and in itself alarming that Europe's Christian culture is barely in a position to uphold Europe's own Christian values?"

Statistics from 2010 by Pew Research showed that under 0.1\% of Hungary's population was Muslim, compared to $7.5 \%$ in France, $5.8 \%$ in Germany and $4.8 \%$ in the UK. While in the beginning of the refugee crisis, civic identity constructions, based on the Copenhagen criteria of the EU from 1994 and Lisbon Treaty of 2009 were dominant, this has changed. Primordial identity construction not only dominates the political elites discourse in the Visegrad states, it also gained momentum in the Western European core states. This discourse based on primordial identity construction changed European refugee politics towards a closure of the Balkan Route. The Austrian foreign minister Johanna Mikl-Leitner said "the most honest thing is to tell the refugees: it's impossible to get through the Balkan route anymore. The Balkan route is closed". 52 Yet, between February and September 2016, still 50,000 asylum seekers nevertheless took the Balkan Route to Germany. ${ }^{53}$

EU Commission President Claude Juncker said countries that want to join the EU have to follow EU norms and rules. Countries that refuse are "losing the right to join the European Union. ${ }^{.54}$ At the same time, to better deal with the huge influx of migrants, the Commission has produced a list of countries to allow fast-track removals. Especially economic migrants from Balkan should be sent home as fast as possible. Furthermore, the EU wants to oblige Northern African peripheral states to take back refugees. Matteo Renzi, the Head of the Italian government, said "Europe, signing as Europe, has to sign repatriation agreements with all the African countries". A failure to do so would put Italy on a confrontation course with the rest of the 28 -nation EU. ${ }^{55}$ At a EU refugee summit in Vienna in September 2016, the EU decided to raise the capacities of FRONTEX (the European Agency for the Management of Operational Cooperation at the External Borders of the Member States of the European Union) to completely close the Balkan Route and to support Macedonia and Bulgaria and others to reach that goal. The EU also plans to sign more agreements with third states, for instance Egypt, and sign repatriation agreement with Afghanistan, Pakistan, and other countries.

The discourse on identity in this critical juncture framed policy options in the EU. While the EU still upholds rhetorically its civic identity construction, it pursues restrictive policies with its agreements. Paradoxically, the changed discourse in the EU and the policies towards its Southern neighbours made global management and coordination within the Group of G20 much more probable. The restrictive policies of the EU resemble stronger those policies of other repellent developed Nations elsewhere. The next sections explore the hard cases in the Asian semiperiphery and core. While the identity construction in EU ideally has a normative approach based on human rights standards and civic identity construction, Asian identity construction as a common minimum standard is based on family values and culture. 


\section{Identity structure and formation on refugees}

Common characteristics of identity in Pacific Asia include emphasis on family, antiindividualism, harmony, gift-giving and social ritual. All Pacific Asian states can be categorized as familial ones. ${ }^{56}$ 'Family' in state-society relations means three aspects: a metaphor for imagining the state, a model for state building, and as a device to change state-policies or a vehicle for state goals. Family is the primary source of identity and solidarity. ${ }^{57}$ Also Confucius made the family the most fundamental social unit. Family was a model for all wider social five relations and for maintaining stability in society. These are between ruler and ruled, father and son, husband and wife, elder brother and younger brother, and between friends. If all are aware of their place and function, then harmony would prevail. In Asian societies it is more difficult to uphold a distinction between public sphere (state affairs) and private sphere. These family values even made it into Constitutions of several Southeast Asian countries. Korea shows the same association of family and ruling values following China's influence. ${ }^{58}$ For example in Indonesia, Art.33 of the Constitution reads "The economy shall be organized as a common endeavour based upon the principle of the family system." Pacific Asian societies traditionally established norms of social behaviour which did not rely much upon state or the law. The family was regarded as a vital institution in maintaining order and became a model for other organisations. Family is the primary source of identity. Most states involve analogies with family relations as basis for political authority. Pacific Asian societies are less individualistic and more disposed to accept the primacy of group identity. They tent to instinctively treat people differently according to whether they are 'insiders' (and outsiders) and they exploit this distinction to pursue their interests. Throughout Asia there is much greater acceptance of hierarchy in social relations, and less enthusiasm for equality than in the West. Policy responses on comparable problems for reasons of identity can be different. Like Germany, also Japan uses demography as an explanation for its refugee policy, but in an opposite direction. Japan. The country, with arguably the highest living standards on earth, wants to improve its own living standards first, before it accepts refugees, said Japan's Premier Shinzo Abe. ${ }^{59}$ He wants to do so by emphasizing family in raising the labour market participation by women.

Another primary preference is the avoidance of disorder and a preference for consensus. When there is a general disgust for disorder or chaos, the order is moral conduct per se. While those above mentioned values are not 'distinct Asian values' (in Europe many people also place family higher than public, and in Asia many may place the public higher than their family). Yet, when traditionally family and household was traditionally regarded as vital institution in maintaining order and providing welfare, then outsiders like migrants and refugees cannot be regarded as family members, but as carriers of disruptive behaviour of this order. In the Asian societies, where anti-individualism is strong, outsiders are treated yet more differently than insiders. To pursue their interests, insiders may exploit outsiders and this may not be regarded as illegitimate by society. Values in Asian societies also change. Many Asian societies need migration because they are lack of workforce. Thailand and Japan are main examples with this regard. An example for incremental change is Korea. In 2010, for the first time ever, a migrant was nationalised.

Malaysia currently hosts one of the largest urban refugee populations in the world. Interestingly, he gives an example about the integration of family values with the 
protection of refugees, which could be seen as equivalent to European human rights standards, but in accordance with the Asian value system: "For it is only when we transcend the silos of race and faith, only when we look at images of desperate migrants, the victims of extremists, and those whose lives are degraded by hunger and poverty - and see not strangers, but our brothers and sisters, [...]. ${ }^{, 60}$ In October 2015, Najib said "People around the world cry out for our help. We cannot, we must not, pass on by".

Malaysia as ASEAN chair in 2015 had to be firmer with Myanmar while persuading other member countries to declare trade sanctions if the situation worsened. ${ }^{61} \mathrm{How}$ ever, this critical juncture may also lead to improved cooperation at regional level as a basic foundation for a global approach. Datuk Anifah Bin Haji Aman, the Minister of Foreign Affairs of Malaysia, opined: "We are working in ASEAN's cooperative way, therefore, member states of ASEAN should come together and to discuss, in order to find a plan which could benefit all of us. Although, ASEAN's stance is not to intervening member states' internal affair, [...]. It's no more the problems of Burma, Malaysia, Indonesia or Thailand. It is an international issue, we will have direct contact with Burma. ${ }^{362}$

Retno Marsudi, Minister of Foreign Affair of Indonesia insisted, Indonesia's participation on humanitarian assistance and sheltering refugees will be under temporary measure: "Indonesia will only sheltering these refugees a year, and will let international society to find more suitable solution to fix the issue in this one year." $\mathrm{He}$ also portrayed Indonesia as a transit state, which is typical for a semiperipheral state: "We are not the 'targeting state' that refugees were planning to go to, we are simply a transfer state to them. We merely offer 1 year for them to stay, with agreement reached by the international society, we will move them back to where they came from.

Making foreigners and migrants "insiders" of Asian societies is the major challenge there. Refugees and migrants are not only individuals often without family, which would already find suspicion in many Asian societies even they are Nationals. Since they are also foreigners, immigrants and refugees face a double stigmatisation.

\section{Towards a global management of refugee management?}

Table 7 summarises assumptions and findings of this article in a world system model. The goal of this paper was to figure out options of coordination on a global management of refugee policy, as stated by various politicians and state leader in Europe and Asia. First, this paper took a look on the empirical data. Illegal migration and the refugee crisis is seen as a global challenge by UNHCR, but also in domestic and regional political institutions. While common consciousness is growing, the data actually revealed that most migration and refuge takes place regionally. Yet, it is also shown that Europe and Asia share many similar problems, and both sides may learn from each other. The data also showed that there are strong similarities when comparing those countries that I called semi-periphery here. These countries usually belong to the emerging markets and the larger of them group within G20, like Turkey or Indonesia. When adding Thailand and Malaysia we find a group of Nations who have a comparable function in a world system of 
Table 7 Flight and migration flows and refugee management in a World System

\begin{tabular}{|c|c|c|c|c|}
\hline & $\begin{array}{l}\text { Flight and } \\
\text { migration } \\
\text { flows }\end{array}$ & $\begin{array}{l}\text { Governments situation and } \\
\text { movement of flight and } \\
\text { migration }\end{array}$ & National Governance & $\begin{array}{l}\text { Towards global } \\
\text { management: } \\
\text { governance from core } \\
\text { to periphery }\end{array}$ \\
\hline Periphery & $\begin{array}{l}\text { Origin and } \\
\text { refuge } \\
\text { destination }\end{array}$ & $\begin{array}{l}\text { failed states, civil war } \\
\text { Weak governance }\end{array}$ & Repression and indifference & $\begin{array}{l}\text { Higher funds for } \\
\text { UNHCR }\end{array}$ \\
\hline $\begin{array}{l}\text { Semi- } \\
\text { Periphery }\end{array}$ & $\begin{array}{l}\text { temporary } \\
\text { residence } \\
\text { and transit }\end{array}$ & $\begin{array}{l}\text { Two identities: primordial } \\
\text { identity construction } \\
\text { domestically; civil identity } \\
\text { towards the global arena } \\
\text { Low to middle income } \\
\text { countries }\end{array}$ & $\begin{array}{l}\text { Tolerant but not supportive for } \\
\text { refugees } \\
\text { Refugees preferably under } \\
\text { UNHCR mandate; integration } \\
\text { mostly informal sector; refugees } \\
\text { seen as opportunity }\end{array}$ & $\begin{array}{l}\text { Deterrence } \\
\text { Central role for } \\
\text { refugee policy } \\
\text { May itself repatriate } \\
\text { refugees to the } \\
\text { periphery } \\
\text { Bargaining between } \\
\text { core and semi- } \\
\text { periphery on costs of } \\
\text { hosting refugees }\end{array}$ \\
\hline Core & $\begin{array}{l}\text { Preferred } \\
\text { target } \\
\text { States }\end{array}$ & $\begin{array}{l}\text { Civic identity construction in } \\
\text { Europe } \\
\text { primordial and family } \\
\text { identity construction in East } \\
\text { Asia } \\
\text { Manipulation of flight and } \\
\text { migration through } \\
\text { interventions }\end{array}$ & $\begin{array}{l}\text { UN Conventions } \\
\text { Regional agreements (EU) } \\
\text { based on international law }\end{array}$ & $\begin{array}{l}\text { Coordination among } \\
\text { core states } \\
\text { Rationalising UN } \\
\text { conventions to limit } \\
\text { migration } \\
\text { Financial help to and } \\
\text { agreements with } \\
\text { semi-periphery }\end{array}$ \\
\hline
\end{tabular}

refugees. These countries host large numbers of refugees going into the millions. Often, the refugees find work in the informal sector. These countries often withhold any social standards for refugees, while human traffickers engage in illegal smuggling of people. These countries may use their strategic position to negotiate "deals" with the core to limit illegal migration.

A central role in global coordination, at least indirectly, is played by the UNHCR. In those countries in the semi-periphery, where refugees and migrants find more than just basic shelter, but also opportunities for making a living, the UNHCR sets standards that may become customary law even in those states that are not Members of the Refugee Convention.

Identity construction is key to understand the refugee policies by the core states in Europe and in Asia. While values in the EU are (ideally) stronger based on a civic culture, in Asia they are (ideally) based on family values. Therefore, the EU is more open for foreigners, at least for those who legally enter its territory. However, the critical juncture in 2015/6 also made the primordial European tradition, which is based on domestic national culture, stronger.

For the core states, coordination with semi-peripheral and peripheral states is central. Higher payments and agreements between the rich states and emerging markets and those states that hose large contingents of refugees is on key issue. Also within the EU, countries like Italy and Greece need more support. Better coordination between the core and the semi-periphery will not solve the problems in those countries where refugees come from, for which other approaches are needed. However, coordination between EU and East Asia may increase the awareness about the interdependences, common problems, options for mutual learning, human rights protection, and fair burden sharing between Europe and Asia and between the core and semiperipheral states. 


\section{Endnotes}

${ }^{1}$ Reuters. Hundreds of refugees arrive in Malaysia and Indonesia after Thai crackdown. 11 may 2015, http://www.reuters.com/article/2015/05/11/us-indonesia-rohingyaidUSKBNONVOPC20150511 accessed 27 September 2016.

${ }^{2}$ Sifton, John.2015. The Diplomat, Asia's Watery Graveyard for Asylum Seekers. 16.05.2015

${ }^{3}$ Antonio Guterres, the UN High Commissioner for Refugees, opined "[f]or an age of unprecedented mass displacement, we need an unprecedented humanitarian response and a renewed global commitment to tolerance and protection for people fleeing conflict and persecution."

${ }^{4}$ Wallerstein, Immanuel. 1974. The Modern World-System I, Academic Press, New York.

${ }^{5}$ Risse, Thomas .2011. A Community of Europeans? Transnational Identities and Public Spheres, CUP.

${ }^{6}$ Quoted in Risse 2011. A community of Europeans.

${ }^{7}$ Figures at a Glance. http://www.unhcr.org/figures-at-a-glance.html

${ }^{8}$ UNHCR. Historical Refugee Data http://data.unhcr.org/dataviz/\#, http://www.globalrefugees.info/, http://www.nytimes.com/interactive/2015/06/21/world/map-flow-desperate-migration-refugee-crisis.html?_r=3 (accessed 27 September 2016).

${ }^{9}$ UNHCR, Syrian Regional Refugee Response, http://data.unhcr.org/syrianrefugees/ regional.php (accessed April 2017).

${ }^{10} \mathrm{https}$ ://www.theguardian.com/world/2015/sep/30/japan-says-it-must-look-after-itsown-before-allowing-syrian-refugees-in

${ }^{11}$ http://www.japantimes.co.jp/news/2016/09/20/national/politics-diplomacy/abe-vows-28-billion-seamless-aid-refugees-host-nations/\#.V-aR160-6Jc accessed 27 September 2016.

${ }^{12}$ The Guardian, Japan says it must look after its own before Syrian refugees let in, 30 September 2015. https://www.theguardian.com/world/2015/sep/30/japan-says-it-mustlook-after-its-own-before-allowing-syrian-refugees-in accessed 27 September 2016.

${ }^{13}$ UNHCR, Northern European Government Donors, http://www.unhcr.org/neu/government-donors

${ }^{14}$ Schuster, Liza. 2011. Turning refugees into 'illegal migrants': Afghan asylum seekers in Europe. Ethnic and Racial Studies. 34/8:1392-1407.

${ }^{15}$ USA Today, Park, Katrin. Japan, Korea deny refugees, USA Today, 15.09.2015.

${ }^{16}$ Koreaportal. South-Korean President Parg Geun Hye vows cooperate against terrorism http://en.koreaportal.com/articles/4623/20151117/south-korean-president-park-ge un-hye-vows-cooperate-against-terrorism.htm, http://www.voanews.com/a/south-korea -faces-criticism-over-refugee-policy/3451163.html

${ }^{17}$ The New York Times. Syrians fleeing Asylum in South Korea Find Only Cold Shoulder. 5 August 2016 http://www.nytimes.com/2016/08/06/world/asia/korea-refugees-syria.html?_r=0 (accessed 27 September 2016.

${ }^{18}$ Eurostat, Asylum Applicants in the EU, http://ec.europa.eu/eurostat/news/themesin-the-spotlight/asylum2016

${ }^{19}$ Die Zeit, 22 September 2016, Mehr als 550000 abgelehnte Asylbewerber leben in Deutschland, http://www.zeit.de/news/2016-09/22/migration-550000-abgelehnte-asylbewerber-leben-in-deutschland-22081005 (accessed 25 April 2017).

${ }^{20} \mathrm{UNHCR}$, Proposals for Action (May 2015), Bay of Bengal and Andaman Sea, p.2. 
${ }^{21}$ Ibid.

${ }^{22}$ Regulation (EU) No 604/2013 of the European Parliament and of the Council of 26 June 2013 establishing the criteria and mechanisms for determining the Member State responsible for examining an application for international protection lodged in one of the Member States by a third-country national or a stateless person.

${ }^{23}$ Bacic, Nika. 2012. Asylum Policy in Europe - The Competences of the European Union and Inefficiency of the Dublin System, Croatian Yearbook of European Law \& Policy. 8: 41-76.

${ }^{24}$ Wunderlich, Daniel. 2013. Towards Coherence of EU External Migration Policy? Implementing a Complex Policy, International Migration. 51/6: 26-40.

${ }^{25}$ European Commission, Migration and Home Affairs, https://ec.europa.eu/home-af fairs/what-we-do/policies/asylum/examination-of-applicants_en

${ }^{26}$ European Council on Foreign Relations. 11 September 2015. Why Germany's Willkommenskultur is a tough model for Eastern Europe to follow, http://www.ec fr.eu/article/commentary_understanding_eastern_european_attitudes_on_refugees4019 accessed 26 September 2016.

${ }^{27}$ Der Spiegel. The Lonely Chancellor. Merkel under fire as refugee crisis in Germany worsens. 2 November 2015, http://www.spiegel.de/international/germany/merkel-underfire-as-refugee-crisis-in-germany-worsens-a-1060720.html accessed September 27, 2016.

${ }^{28}$ The Wall Street Journal. Asean's Toothless Council. 22 July 2009, http:// www.wsj.com/articles/SB10001424052970203517304574303592053848748 accessed 27 September 2016.

${ }^{29}$ AICHR, ASEAN Intergovernmental Commission on Human Rights, http:// aichr.org/external-relations/aichr-and-unhcr/

${ }^{30}$ Kneebone, Susan.2014. The Bali Process and Global Refugee Policy in the Asia Pacific Region. Journal of Refugee Studies. 24/4: 596-618.

${ }^{31}$ New Mandela. ASEAN can learn from Europe's refugee crisis. 24 September 2015, http://www.newmandala.org/asean-can-learn-from-europes-refugee-crisis/ 26 September 2016.

${ }^{32}$ Hourdequin, Pierre.2007. Malaysia's 2005-2006 refugee stand-off with Thailand: a security culture analysis. International Relations of the Asia-Pacific. 8/2: 175-190.

${ }^{33}$ Palatino, Mong. 2014. Malaysia Accused of Mistreating Refugees. The Diplomat, 3 December 2014.

${ }^{34}$ Savitri Taylor (2016): Growing Pains: the Asia Pacific Refugee Rights Network at seven years, Cosmopolitan Civil Societies Journal, 8(2): 4734.

${ }^{35}$ Vas Dev, Sanjugata. 2009. Accounting for State Approaches to Asylum Seekers in Australia and Malaysia: The Significance of "National" Identity and "Exclusive" Citizenship in the Struggle Against "Irregular" Mobility. Identities. 16/1:33-60.

${ }^{36}$ Rowe, Elizabeth, O’Brien, Erin. 2014. 'Genuine' refugees or illegitimate 'boat people': Political constructions of asylum seekers and refugees in the Malaysia Deal debate. Australian Journal of Social Issues. 49/2: 171-193.

${ }^{37}$ Palmgren, Pei A. 2014. Irregular Networks. Bangkok Refugees in the City and Region. Journal of Refugee Studies. 27/1: 21-41.

${ }^{38}$ Bagenal, Flora.2014. Southeast Asia seen falling Myanmar's persecuted Rohingya Muslims. Christian Science Monitor, 26.2.2014.

${ }^{39}$ UNHCR, Global Focus, Malaysia, http://reporting.unhcr.org/node/2532 
${ }^{40}$ Fresia, Marion. 2014. Building Consensus within UNHCR's Executive Committee: Global Refugee Norms in the Making. Journal of Refugee Studies. 27/4: 514-533.

${ }^{41}$ UNHCR, Global Focus, Thailand, http://reporting.unhcr.org/node/2552

${ }^{42}$ Gammeltoft-Hansen, Hans. 2014. International Refugee Law and Refugee Policy: The Case of Deterrence Policies, Danish Institute for Human Rights, Copenhagen.

${ }^{43}$ Coalition 2013:, The Coalition's Policy for a Regional Deterrence Framework to Combat People Smuggling, Parliament of Australia, http://parlinfo.aph.gov.au/par IInfo/search/display/display.w3p;query=Id\%3A\%22library\%2Fpartypol\%2F2686733\%22 (accessed April 20, 2017).

${ }^{44}$ Deutsche Welle, Gabriel Dominguez, No country for refugees? Japan and South Korea`s tough asylum policies, 4 November 2014, http://www.dw.com/en/no-country-for-refugeesjapan-and-south-koreas-tough-asylum-policies/a-18037765 accessed 26. September 2016.

${ }^{45}$ Wolman, Andrew. 2015. Japan and international refugee protection norms: Explaining non-compliance. Asia and Pacific Migration Journal, 24: 409-431.

${ }^{46}$ Wolman, Andrew. 2013. Korea's Refugee Act: A Critical Evaluation under International Law. Journal of East Asia \& International Law. 6/2: 479-480.

${ }^{47}$ Pollmann, Mina. 2015. Japan's Role in the Refugee Crisis, The Diplomat, 11 September 2015.

${ }^{48}$ International Organization for Migration (IOM), How The World Views Migration, Global Migration Data Analysis Centre, 2015.

${ }^{49}$ The Independent. Mediterranean migrant crisis: Furious Italian PM Matteo Rizzi forces belated compromise on quotas at EU leaders summit. 26 June 2015, http://www.independent.co.uk/news/world/europe/mediterranean-migrant-crisis-furio us-italian-pm-matteo-renzi-forces-belated-compromise-on-quotas-at-10349039.html accessed 27 September 2016.

${ }^{50}$ The Conservative Tree House. The Last Refuge. Socialist Hollande To Deny Opinion and France's Doors To Mid-East "Refugees". 7 September 2015, http://theconservativetreehouse.com/2015/09/07/socialist-hollande-to-deny-public-opinion-and-open-

frances-doors-to-mid-east-refugees/(accessed 27 September 2016).

${ }^{51}$ The Independent. Far-rights rise and dehumanising of conflict victims are greatest barriers to join European action. 8 September 2015, http://www.independent.co.uk/ news/world/europe/refugee-crisis-far-rights-rise-and-dehumanising-of-conflict-victimsare-greatest-barriers-to-joint-10492109.html

${ }^{52}$ Times Free Press. The Latest. Austrian minister says Balkan route is closed, 10 March 2016. http://www.timesfreepress.com/news/national/international/story/2016/mar/10 /latest-austriminister-says-balkroute-closed/354504/accessed 27 September 2016.

${ }^{53}$ Frankfurter Allgemeine Zeitung. Die Balkanroute soll noch aussichtsloser werden, 24 September 2016, http://www.faz.net/aktuell/politik/fluechtlingskrise/balkanroutesoll-fuer-fluechtlinge-aussichtslos-werden-14451272.html accessed 27 September 2016.

${ }^{54}$ The Telegraph, Juncker calls for 'compulsary' resdistribution of 160000 refugees. 9 September 2015, http://www.telegraph.co.uk/news/worldnews/europe/eu/11852782/ Jean-Claude-Juncker-State-of-the-Union-EU-address-refugee-crisis-live.html (accessed 27 September 2016).

${ }^{55}$ Reuters. Italy's Renzi wants EU on refugees as neighbors block border crossings, 14 June 2015. http://www.reuters.com/article/2015/06/14/us-europe-migrants-italy-idUSKBN0OU0A320150614 accessed 27 
${ }^{56}$ Haney, Lynne and Lisa Pollard (eds), Families of a New World, Routledge, Abingdon and New York, 2003.

${ }^{57}$ Ferdinand, Peter, Governance in Pacific Asia. Political Economy and Development from Japan to Burma, Continuum, New York and London, 2012, p. 48.

${ }^{58}$ Ferdinand (2012), p. 51.

${ }^{59}$ The Japan Times. Abe pledges $\$ 2.8$ billion to promote 'self-reliance' among refugees, vows to take leading role in crisis, 30 September 2015.

${ }^{60}$ Malaysiakini, Najib. Malaysia to accept 3000 Syrian refugees. 2 October 2015, https://www.malaysiakini.com/news/314238 accessed 27 September 2016.

${ }^{61}$ AA. Expel Myanmar from ASEAN over Rohingya: Malaysian ex-PM, 12 June 2015. http://www.aa.com.tr/en/world/expel-myanmar-from-asean-over-rohingya-malaysianex-pm/37240 accessed 27 September 2016.

${ }^{62}$ Nanyang Post. A meeting between ministers of foreign affair of Malaysian, Indonesia and Thailand, 21th of May, 2015.馬來西亞外長 阿尼法说:“我们是在东盟合 作精神下行事,因此东盟成员国之间应共同讨论, 以找出一个惠及全体成员国的方 案。虽然东协的立场是不干涉成员国的内部事务, 在这课题上我们还是要先聆听缅甸 在解决相关课题是否面对一些困难。“这不再是缅甸、马来西亚、印尼或泰国的问 题。这已是国际课题,(online not accessible any more, translated by the author)

${ }^{63}$ Ibid., 印尼外交部长勒特诺马苏蒂强调,印尼参与人道援助及收留海上难民只是临时 措。“印尼只会收留这些难民一年,并交由国际社会在这一年内商讨采取更妥善的解决 方案。“我们不是这些难民准出逃的目国家,只是过境国家。我们只提供一年的便利,并 在获得国际社会同意后,将会把这些难民遣返原居国。

Acknowledgment

An earlier version of this paper was presented at "The 2015 Sizihwan International Conference on Asia-Pacific Studies" on "Identity and Integration: Competing Dynamics in Asia-Pacific" at National Sun Yat-sen University in Kaohsiung, Taiwan (November 12-14, 2015). The author is thankful for the comments made at the conference and by reviewers of this journal.

Funding

None

Competing interests

The authors declare that they have no competing interests.

\section{Publisher's Note}

Springer Nature remains neutral with regard to jurisdictional claims in published maps and institutional affiliations. 